\title{
Elektif Sezaryen Ameliyatlarında Kullanılan Anestezi Yönteminin Ağrı Anksiyete ve Hasta Memnuniyeti Üzerine Etkisi
}

\section{The Effect of Anaesthetic Method Used in the Elective Cesarean Section on Pain, Anxiety and Patient Satisfaction}

Sinan Kızılkaya ${ }^{1}$,

Aybars Tavlan²,

Gülçin Hacıbeyoğlu²,

Şule Arıcan²,

Sema Tuncer Uzun²

${ }^{1}$ Akdeniz Üniversitesi Anesteziyoloji ve Reanimasyon Anabilim Dalı, Yoğun Bakım Bilim Dalı, Antalya, Türkiye

${ }^{2}$ Necmettin Erbakan Üniversitesi, Meram Tıp Fakültesi, Anesteziyoloji ve Reanimasyon Anabilim Dalı, Konya, Türkiye

Geliş Tarihi/Received: 20 Ağustos 2018 Kabul Tarihi/Accepted: 17 Eylül 2019

Yazışma Adresi: Sinan Kızılkaya, Akdeniz Üniversitesi Anesteziyoloji ve Reanimasyon Anabilim Dalı, Yoğun Bakım Bilim Dalı, Antalya,Türkiye

e mail: drsinankizilkaya@hotmail.com

\section{ORCID}

Sinan Kızılkaya

https://orcid.org/0000-0001-9365-9645 Aybars Tavlan

https://orcid.org/0000-0002-6064-0179 Gülçin Hacıbeyoğlu

https://orcid.org/0000-0002-9438-3414

Şule Arıcan

https://orcid.org/0000-0002-8634-1150

Sema Tuncer Uzun

https://orcid.org/0000-0002-6205-1706
Öz

Amaç: Elektif sezaryen operasyonlarında anestezi yönteminin anksiyete, hasta memnuniyeti ve ağrı düzeyine etkisinin araştırılması ek olarak hizmet kalitesi hakkında bilgi edinmek amaçlanmıştır. Hastalar ve Yöntem: Genel Anestezi (GA) veya Spinal Anestezi (SA) ile sezaryen planlanan gönüllülerde prospektif anket çalışması şeklinde gerçekleştirildi. Anksiyete düzeyleri Durumluluk Anksiyete Ölıçeği(STAI-D) ile, ağrı düzeyleri Vizüel Analog Skala(VAS) skorlarıyla, memnuniyet düzeyleriyse Memnuniyet-Derlenme Kalitesi (QoR40T )Ölçeğiyle değerlendirildi.

Bulgular: Sezaryen deneyimi olan hastaların preoperatif anksiyete düzeyi daha düşüktü $(p<0,05)$ Her iki grupta da postoperatif anksiyete düzeyleri preoperatif döneme göre anlamlı derecede düşüktü $(p<0,05)$. SA uygulanan grubun 6 . ve 24 . saat VAS değerleri, GA uygulanan gruba göre anlamlı derecede yüksekti $(p<0,05)$. SA uygulanan grubun 24 . saat VAS değerleri 6. saat VAS değerlerinden yüksekti $(p<0,05)$. GA uygulanan grupta ise 24 . saat VAS değerleri 6 . Saat VAS değerlerinden düşüktü $(p<0,05)$. Baş ağrısı şikayeti SA grubunda, boğaz ağrısı şikayeti GA grubunda yüksekti $(p<0,05)$. Her iki grupta da VAS değerleri ile memnuniyet anketinin alt grubu olan ağrı parametreleri arasında negatif yönlü korelasyon saptandı $(p<0,05)$.

Sonuç: Tercih edilen anestezi yönteminin anksiyete ve memnuniyet üzerine etkisinin olmadığı, ağrı algoritmamızın gözden geçirilerek memnuniyet düzeyinin ve hizmet kalitesinin artırılacağı kanısına varıldı.

Anahtar Kelimeler: Sezaryen, Genel anestezi, Spinal anestezi, Anksiyete, Ağrı, Memnuniyet

\section{Abstract}

Aim: It was aimed to get information about service quality as well as searching the effect of anesthetic method on anxiety, patient satisfaction and pain levels in elective cesarean sections.

Patients and Methods: The research was performed as prospective survey study with the volunteers to be subject to C-section through General Anesthesia (GA) or Spinal Anesthesia. Anxiety levels and pain levels of the patients were assessed through State-Trait Anxiety Inventory (STAI-D) and Visual Analog Scale (VAS), respectively. Besides, Quality of Satisfaction-Recovery (QoR40T) Scale was used to evaluate their satisfaction levels.

Results: Preoperative anxiety levels of the patients with cesarean experience was lower $(p<0.05)$. Postoperative anxiety levels of both groups were significantly lower than their preoperative anxiety levels $(p<0.05)$. VAS values of SA group for hours 6 and 24 were significantly higher than those of GA group $(p<0.05)$. On the other hand, VAS values of SA group for hour 24 were higher than those for hour $6(p<0.05)$. In contrast, VAS values of GA group for hour 24 were found to be lower than those for hour $6(p<0.05)$. SA group complained about headache most while throat ache was the most-frequent complaint among GA group $(p<0.05)$. A negative correlation between VAS values and the sub-group of the satisfaction survey, pain parameters was determined in both groups $(p<0.05)$

Conclusion: It was concluded that the anesthetic method preferred did not affect anxiety and satisfaction. Furthermore, it was understood after reviewing the pain algorithm that satisfaction level and service quality should be raised.

Key words: Cesarean section, General anesthesia, Spinal anesthesia, Anxiety, Pain, Satisfaction
Atıf yapmak için: Kızılkaya S, Tavlan A, Hacıbeyoğlu G, Arıcan Ş, Uzun ST Elektif Sezaryen Ameliyatlarında Kullanılan Anestezi Yönteminin Ağrı Anksiyete ve Hasta Memnuniyeti Üzerine Etkisi. Selcuk Med J 2020;36(3): 192-198
Açıklama: Yazarların hiçbiri, bu makalede bahsedilen herhangi bir ürün aygıt veya ilaç ile ilgili maddi çıkar ilişkisine sahip değildir. Araştırma, herhangi bir dış organizasyon tarafından desteklenmedi. Yazarlar çalışmanın birincil verilerine tam erişim izni vermek ve derginin talep ettiği takdirde verileri incelemesine izin vermeyi kabul etmektedirler. 


\section{GíRiş}

Anksiyete, bireyin kendini güvende hissetmediği durumlara karşı geliştirdiği psikolojik bir tepkidir. Cerrahi girişimin türü ne olursa olsun, ameliyat kararı alınması hastalarda anksiyete oluşturur (1). Bu durum ise postoperatif iyileşme ve hasta memnuniyetini olumsuz etkileyerek hizmet kalitesini düşürür (2). Gebelerde uygun bir anestezik yaklaşım için hastanın psikolojik durumunun belirlenmesi, anksiyete düzeyi ve anksiyetenedenlerinin saptanması çok önemlidir. Çünkü gebelik sürecinde nörohormonal değişiklikler sebebiyle anksiyete düzeyleri artarak; cerrahiyi, anesteziyi, postoperatif iyileşmeyi ve hasta memnuniyetini olumsuz etkiler (2). Sağlık hizmet kalitesinin belirlenmesinde hasta görüşleri önemlidir ve sadece klinik ölçütlerle yapılan değerlendirmeler yetersiz kabul edilir (3-5). Günümüzde sağlık hizmeti vermekle yükümlü olan kuruluşların; hizmet kalitesinin değerlendirilmesinde, hasta görüşlerine dayanan anket çalışmalarıyla sundukları hizmeti periyodik olarak değerlendirmeleri kaçınılmaz olmuştur.

Çalışmada, primer olarak elektif sezaryen operasyonlarında seçilen anestezi yönteminin anksiyete, hasta memnuniyeti ve ağrı düzeyine etkisinin araştırılması sekonder olarak da hizmet kalitesi hakkında bilgi edinmek amaçlanmıştır.

\section{HASTALAR VE YÖNTEM}

Çalışma, Necmettin Erbakan Üniversitesi Meram Tıp Fakültesi etik kurulunun 2017/956 sayılı onayı alınarak, Haziran 2017-Ağustos 2017 tarihleri arasında Kadın Hastalıkları ve Doğum Anabilim Dalı Ameliyathanesi'nde elektif sezaryen operasyonu planlanan hastalar üzerinde gerçekleştirildi. Çalışma ile ilgili bilgiverilip yazılı onayları alınan, anket sorularını anlayabilecek mental duruma sahip, 18-45 yaşarası, ASA I-III risk grubunda,160 gönüllü gebe çalışmaya dahil edildi. Psikiyatrik bozukluğu olan, antikoagülan kullanan, rejyonel anestezinin kontrendike olduğu, rejyonel anestezinin başarısız olması nedeniyle genel anestezi uygulanan ve okur - yazar olmayan hastalar çalışma dışı bırakıldı. Çalışmaya katılmayı kabul eden gebelerin demografik verileri (yaş, yaşadığı yer, eğitim düzeyi, doğum sayısı, sezaryen deneyimi) kaydedildi. Uygulanacak anestezi yöntemi; anestezi uzmanı, kadın-doğum uzmanı ve hastanın ortak kararı ile belirlendi.Çalışmayı yürüten ekip ise bu sürece dahil olmadı. Genel anestezi uygulanan hastalar Grup GA, Spinal anestezi uygulanan hastalar ise Grup SA olarak isimlendirildi.

Hastalarda, uygulanacak anestezi yöntemi belirlendikten sonra, preoperatif ve postoperatif anlık anksiyete düzeylerinin değerlendirilmesi için Durumluluk Anksiyete Ölçeği (STAI-D) kullanıldı. STAI 1964 yılında Speilberger ve Gorsuch tarafından; Cattell ve Scheier'in, Taylor'in ve Welsh' in anksiyete skalalarından faydalanılarak geliştirilmiş ve Necla Öner tarafından Türkçeye çevrilmiştir (6).

Yirmi sorudan oluşan ve $20-80$ arasında bir puan elde edilen STAI-D anketi, operasyon öncesinde ve sonrasında 6 . saatte hastalara uygulandı. Otuz yedi puan üzeri anksiyete olarak değerlendirildi ( $\leq 36$ kaygı yok, 37-41 hafif kaygı, $\geq 42$ yüksek kaygı). Anestezi ekibi tarafından kliniğin rutin uygulaması olarak Grup GA'da doğum eylemi gerçekleştikten sonra $20 \mathrm{mg}$ tenoksikam ve $2 \mathrm{mg} / \mathrm{kg}$ tramadol hidroklorik asit intravenöz yoldan uygulandı. Grup SA'da ise ek analjezik uygulanmadı. Hastaların ağrı şiddetlerinin değerlendirilmesinde postoperatif 6 . ve 24 . Saatte Vizüel Analog Skala (VAS) skorları kullanıldı. Hasta memnuniyetinin değerlendirilmesinde postoperatif 24 . saatte; emosyonel durum, fiziksel konfor, psikolojik destek, fiziksel bağımlılık ve ağrı alt komponentlerini içeren 40 sorudan oluşan Memnuniyet-Derlenme Kalitesi Ölçeği (Quality of Recovery: QoR40 T) anketi uygulandı. Postoperatif hasta memnuniyetini değerlendirmede kullanılan en önemli test olan Memnuniyet-Derlenme Kalitesi ölçeği (Quality of Recovery: QoR 40 T) Myles tarafından geliştirilmiştir. $\mathrm{Bu}$ ölçek ameliyat sonrası iyileşmenin kalitesini ölçen geçerli ve güvenli bir ölçektir (7).Cevapların değerlendirilmesinden 40-200 arasında bir puan elde edildi.

Elde edilen veriler SPSS 22.0 bilgisayar programı kullanılarak analiz edildi. Verilerin normal dağılıma uygunluk analizi Kolmogrov-Smirnov testi ile yapıldı. Tanımlayıcı istatistikler ortalama \pm standart sapma ve $\%$ ile ifade edildi. Kategorik verilerin karşılaştırmasında Ki Kare testi kullanıldı. Gruplar arası karşılaştırmada Mann-Whitney $U$ testi ve Wilcoxon testi kullanıldı. Grup sayısının ikiden çok olduğu durumlarda ve tekrarlayan ölçümlerde One-Way ANOVA varyans analizi kullanıldı. Grupların anket sonuçlarının doğruluğu korelasyon katsayıları ve istatistiksel anlamlılık Pearson testi ile hesaplandı. Güç analizi $\% 95$ olarak tespit edildi ve $p<0,05$ anlamlılık düzeyi olarak kabul edildi.

\section{BULGULAR}

Hastaların yaş ortalaması Grup SA'da 29,59 $\pm 5,59$

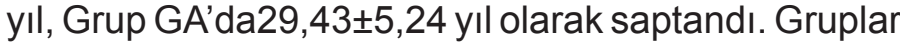
arasında yaş, yaşanılan yer, eğitim düzeyi, doğum 
Tablo 1. Yaşadığı yer, eğitim düzeyi ve sezaryen deneyimininpreoperatif ve postoperatif anksiyete düzeyi ile ilişkisi

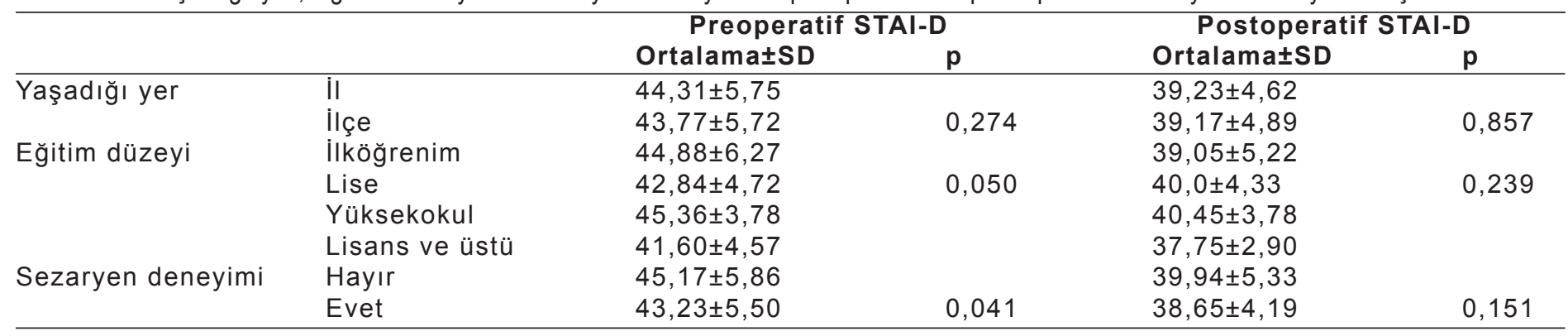

Tablo 2. Grupların preoperatif ve postoperatif anksiyete düzeylerinin karşılaştırılması

\begin{tabular}{|c|c|c|c|c|}
\hline & & Grup SA(n=80) n (\%) & Grup GA(n=80) n (\%) & $\mathbf{p}$ \\
\hline \multirow[t]{3}{*}{ Preoperatif } & Kaygı yok & $8(10)$ & $7(8,7)$ & \multirow{3}{*}{0,446} \\
\hline & Hafif kaygı & $16(20)$ & $24(30)$ & \\
\hline & Yüksek kaygı & $56(70)$ & $49(61,3)$ & \\
\hline \multirow[t]{3}{*}{ Postoperatif } & Kaygı yok & $20(25)$ & $24(30)$ & \multirow{3}{*}{0,648} \\
\hline & Hafif kaygı & $39(48,8)$ & $35(43,8)$ & \\
\hline & Yüksek kaygı & $21(26,2)$ & $21(26,2)$ & \\
\hline
\end{tabular}

sayısı ve önceki sezaryen deneyimleri gibi demografik veriler açısından anlamlı fark yoktu ( $p>0,05)$.

Demografik veriler ile preoperatif anksiyete düzeyleri kıyaslandığında sadece daha önce sezaryen deneyimi olan hastaların preoperatifanksiyete düzeyi istatistiksel olarak anlamlı derecede düşüktü $(p<0,05)$ (Tablo 1). Preoperatif ve postoperatif dönemlerde kaygı duyan birey sayılarında istatistiksel olarak anlamlı fark yoktu (Tablo 2). Preoperatif ve postoperatif dönemde gruplar arası STAI-D skorları arasında istatistiksel olarak anlamlı fark yok iken preoperatifanksiyete düzeylerinin her iki grupta da postoperatif dönemde düştüğü saptandı $(p<0,05)$ (Tablo 3).

VAS skorları gruplar arası kıyaslandığında spinal anestezi uygulanan grubun 6 . ve 24. saatteki VAS skorları anlamlı olarak yüksek saptandı $(p<0,05)$. Grupların VAS skorlarındakideğişim değerlendirildiğinde spinal anestezi uygulanan grupta 24. saat VAS düzeyi 6. saate kıyasla anlamlı derecede yüksek saptandı $(p<0,05)$. Genel anestezi uygulanan grupta ise 24 . saat VAS düzeyi 6 . saate kıyasla anlamlı derecede düşük saptandı $(p<0,05)$ (Tablo 4). Postoperatif dönemde grupların memnuniyet düzeyleri incelendiğinde; fiziksel konfor, emosyonel durum, fiziksel bağımlılık, psikolojik destek, ağrı ve toplam skorlarında istatistiksel fark saptanmadı ( $p>0,05)$. Ağrıparametrelerinden baş ağrısı şikayeti Grup SA'da, boğaz ağrısı şikayeti Grup GA'da yüksek saptandı $(p<0,05)$ (Tablo 5). Her iki grupta; preoperatif STAI-D ile postoperatif STAI-D'nin vepostoperatif 6. saat VAS skorları ile 24. saat VAS skorlarınınpozitif yönlükorelasyon gösterdiği saptandı (Tablo 6). VAS skorları ile memnuniyet anketinin alt grubu olan ağrı parametrelerinde ise negatif yönlü korelasyon

Tablo 3. Preoperatif ve postoperatifdönemde anksiyete düzeylerinin karşılaştırılması

\begin{tabular}{llll}
\hline & $\begin{array}{l}\text { Grup SA }(\mathbf{n = 8 0}) \\
\text { Ortalama } \pm \text { SD }\end{array}$ & $\begin{array}{l}\text { Grup GA }(\mathbf{n = 8 0}) \\
\text { Ortalama } \mathbf{S D}\end{array}$ & $\mathbf{p}$ \\
\hline Preoperatif & $44,18 \pm 6,05$ & $43,93 \pm 5,40$ & 0,777 \\
Postoperatif & $39,47 \pm 5,22$ & $38,93 \pm 4,19$ & 0,463 \\
\hline
\end{tabular}

Tablo 4. Postoperatif 6.saat ve 24.saat VAS skorlarının grup içi ve gruplar arası karşılaştırılması

\begin{tabular}{llll}
\hline & $\begin{array}{l}\text { 6. saat VAS } \\
\text { Ort } \pm \text { SS }\end{array}$ & $\begin{array}{l}\text { 24. saat VAS } \\
\text { Ort } \pm \text { SS }\end{array}$ & p \\
\hline Grup SA $(n=80)$ & $5,04 \pm 2,189$ & $5,19 \pm 2,144$ & $<0,001$ \\
Grup GA $(n=80)$ & $4,21 \pm 2,270$ & $3,98 \pm 2,143$ & $<0,001$ \\
p & 0,018 & $<0,001$ & \\
\hline
\end{tabular}


Tablo 5. QoR40 ağrı memnuniyet ortalamalarının gruplararası karşılaştırılması

\begin{tabular}{|c|c|c|c|}
\hline & $\begin{array}{l}\text { Grup SA }(n=80) \\
\text { Ort } \pm S S\end{array}$ & $\begin{array}{l}\text { Grup GA }(n=80) \\
\text { Ort } \pm \text { SS }\end{array}$ & $\mathbf{p}$ \\
\hline Orta Şiddetli ağrı & $3,34 \pm 0,98$ & $3,29 \pm 0,97$ & 0,717 \\
\hline Şiddetli ağrı & $3,67 \pm 1,13$ & $3,90 \pm 1,12$ & 0,145 \\
\hline Baş ağrısı & $4,04 \pm 1,01$ & $4,49 \pm 0,67$ & $0,002^{*}$ \\
\hline Kas ağrısı & $3,64 \pm 1,20$ & $3,82 \pm 1,24$ & 0,208 \\
\hline Sırt ağrısı & $3,67 \pm 1,13$ & $3,90 \pm 1,12$ & 0,145 \\
\hline Boğaz ağrısı & $4,69 \pm 0,83$ & $4,27 \pm 0,94$ & $0,000^{*}$ \\
\hline Ağızda yaraya bağlı ağrı & $4,76 \pm 0,81$ & $4,82 \pm 0,55$ & 0,554 \\
\hline Ağrı Toplam Skoru & $32,37 \pm 4,59$ & $32,82 \pm 4,40$ & 0,624 \\
\hline
\end{tabular}

Tablo 6. Testlerin korelasyonu

\begin{tabular}{|c|c|c|c|c|c|c|c|}
\hline & & & $\begin{array}{l}\text { STAI-D } \\
\text { Preop }\end{array}$ & $\begin{array}{l}\text { STAI-D } \\
\text { Postop }\end{array}$ & $\begin{array}{l}\text { VAS } \\
6 . \text { saat }\end{array}$ & $\begin{array}{l}\text { VAS } \\
\text { 24. saat }\end{array}$ & QoR-40 \\
\hline \multirow{5}{*}{$\begin{array}{l}\text { GRUP SA } \\
(n: 80)\end{array}$} & STAI-D Preop & $\mathrm{R} / \mathrm{P}$ & & $0,790 * * /<0,001$ & $-0,068 / 0,548$ & $-0,138 / 0,222$ & $-0,058 / 0,609$ \\
\hline & STAI-D Postop & $\mathrm{R} / \mathrm{P}$ & $0,790 * /<0,001$ & & $-0,055 / 0,628$ & $-0,209 / 0,051$ & $-0,103 / 0,363$ \\
\hline & VAS 6 . saat & $\mathrm{R} / \mathrm{P}$ & $-0,068 / 0,548$ & $-0,055 / 0,628$ & & $0,496 * / 0,000$ & $0,194 / 0,084$ \\
\hline & VAS 24. saat & $\mathrm{R} / \mathrm{P}$ & $-0,138 / 0,222$ & $-0,209 / 0,051$ & $0,496 * /<0,001$ & & $0,091 / 0,423$ \\
\hline & QoR 40 & $\mathrm{R} / \mathrm{P}$ & $-0,058 / 0,609$ & $-0,103 / 0,363$ & $0,194 / 0,084$ & $0,091 / 0,423$ & \\
\hline \multirow{5}{*}{$\begin{array}{l}\text { GRUP GA } \\
(n: 80)\end{array}$} & & & & & & & \\
\hline & $\begin{array}{l}\text { STAI-D Preop } \\
\text { STAI-D Poston }\end{array}$ & $\begin{array}{l}R / P \\
R / P\end{array}$ & & $0,682^{* *} /<0,001$ & $\begin{array}{l}-0,090 / 0,430 \\
-0,121 / 0.286\end{array}$ & $\begin{array}{l}0,108 / 0,342 \\
0,054 / 0636\end{array}$ & $-0,143 / 0,206$ \\
\hline & VAS 6 . saat & $\mathrm{R} / \mathrm{P}$ & $\begin{array}{c}0,682^{*} /<0,001 \\
-0,090 / 0,430\end{array}$ & $-0,121 / 0,286$ & $-0,121 / 0,280$ & $0,483^{*} / 0,000$ & $\begin{array}{l}-0,126 / 0,266 \\
-0,149 / 0,188\end{array}$ \\
\hline & VAS 24. saat & $\mathrm{R} / \mathrm{P}$ & $0,108 / 0,342$ & $0,054 / 0,636$ & $0,483^{*} /<0,001$ & & $-0,202 / 0,073$ \\
\hline & QoR 40 & $\mathrm{R} / \mathrm{P}$ & $-0,143 / 0,206$ & $-0,126 / 0,266$ & $-0,149 / 0,188$ & & $-0,202 / 0,073$ \\
\hline
\end{tabular}

saptandı (Tablo 7). Diğer veriler arasında korelasyon saptanmadı.

\section{TARTIŞMA}

Cerrahi işlemin kendisi ve işlem için yapılan anestezi uygulamaları hasta tarafından tehlike olarak algılanır ve bu algılama gerek preoperatif gerekse postoperatif anksiyeteye yol açar (8-10). Anksiyete ise postoperatif iyileşmeyi, hasta memnuniyetini olumsuz etkiler ve dolayısıyla hasta hizmet kalitesini düşürür (5). Obstetrik operasyon geçirecek hastaların, genel cerrahi popülasyonuna göre daha yüksek preoperatif anksiyeteye sahip olduğu bildirilmiştir $(11,12)$. Yaş ile preoperatif anksiyete düzeyi arasındaki ilişki hakkında literatürde farklı sonuçlar vardır. Yaşlı hastalarda preoperatif anksiyete skorlarının, genç ve orta yaşlılara göre düşük olduğunu tespit eden çalışmalarda;

Tablo 7. VAS skorlarının QoR40 ağrı memnuniyeti ile karşılaştırılması

\begin{tabular}{llcc}
\hline & & \multicolumn{3}{c}{ Ağrı memnuniyeti } \\
& & $\mathbf{r}$ & $\mathbf{p}$ \\
\hline Grup SA & VAS (6. saat) & $-0,365$ & $<0,001$ \\
$(\mathrm{n}=80)$ & VAS (24. saat) & $-0,385$ & $<0,001$ \\
Grup GA & VAS (6. saat) & $-0,410$ & $<0,001$ \\
$(\mathrm{n}=80)$ & VAS (24. saat) & $-0,568$ & $<0,001$ \\
\hline
\end{tabular}

yaşlılarda kadercilik, gençlerde ise iletişim araçlarını daha etkin kullanmanın bu sonuçlarda etkili olduğunu kanaatine varılmıştır(13-15). Bazı çalışmalarda da genç yaşlarda anksiyete düzeylerinin daha düşük olduğu tespit edilmiştir $(16,17)$. Bu sonuç ise Sağlık Okur Yazarlığı düzeyi ile ilişkili olabilir. Sağlık Okur Yazarlığı okuma-yazma becerilerine ek olarak sağlık konuları hakkında bilgi gerektirir ve sağlıklı davranışlar, ilaçların doğru kullanımı, sağlık hizmetlerinden nasıl yararlanacağını bilmek, öz bakım ile hastalık yönetimi hakkında kararlar verebilme yetisini kapsar. Sağlık Okur Yazarlığının en yüksek olduğu yaş grubunun \%20.8'lik seviyesi ile 35-44 yaşhemen ardından da \%19,7 oranı ile 25-34 yaş olduğu saptanmıştır (18). Çalışmada, hasta gruplarının 18-45 yaş arası gençlerden oluşması, geçirilecek operasyon türünün aynı olması sebebiyle gerek operasyonda gerekse operasyon sonrasında benzer kaygıların oluşması ve Sağlık Okur Yazarlığı seviyelerinin benzer olması sebebiyle yaş ve anksiyete düzeyi arasında anlamlı bir fark gözlenmemiştir. Kırsal bölgeden hastaneye ve hekime ulaşmadaki zorluklar, iş hayatına uzun süre ara verme gibi çevresel faktörler anksiyeteye yol açabilir (19). Hastalarımızda çevresel faktörlerle ilgili stresin benzer olması yaşanılan yer ile anksiyete arasında ilişki çıkmamasına neden olmuştur. 
Preoperatif anksiyete ve eğitim düzeyi arasındaki ilişki araştıııldığında, bilgi düzeyinin anksiyeteyi olumlu ya da olumsuz etkileyebileceği belirtilmiştir. $\mathrm{Bu}$ durum gelişebilecek komplikasyonların olumlu ya da olumsuz sonuçlarının kişi tarafından daha iyi değerlendirilmesine bağlanmıştır $(13,17)$. Çalışmada eğitim düzeyi ile anksiyete arasında ilişki saptanmadı. Bu sonuçta; sosyo-kültürel yapı, Sağlık Okur Yazarlığı seviyelerinin aynı düzeyde olması ve operasyona girecek ekibin araştırılarak seçilmesi gibi faktörlerin etkili olduğu kanısındayız.

Geçirilecek operasyon, anestezi korkusu, ağrı ve diğer komplikasyonların oluşturduğu anksiyete, çocuk sayısı ile ilgili oluşabilecek anksiyeteyi arka planda bırakabilmektedir (2). Birçok çalışma, koşullu öğrenme modeline bağlı olarak, geçmiş cerrahi deneyimlerin preoperatif anksiyeteyi azalttığını göstermiştir. Aynı operasyonu geçiren bireylerin yaşadıkları tecrübe, farkındalıklarını artırarak korkulan durumun aslında o kadar da yüksek risk içermediği kanaatine varmalarına neden olmaktadır $(19,20)$. Bizimçalışmamızda da çocuk sayısının preoperatif anksiyete düzeylerini etkilemediği, sezaryen deneyimi olan hastaların ise preoperatif anksiyete düzeylerinin anlamlı derecede düşük olduğu tespit edildi. Preoperatif anksiyete insidansı, cerrahinin büyüklüğüne ve anestezi yöntemine bağlı olarak \%11-80 arasında değişiklik gösterir $(21,22)$. Çalışmada preoperatif STAI-D skorları postoperatif STAI-D skorlarından anlamlı derecede yüksekti. Gruplar arasında ise preoperatif ve postoperatif dönem anksiyete düzeylerinde anlamlı fark yoktu. Her iki grupta da postoperatif dönemde anksiyete düzeylerinin düşme nedeni, doğum sürecinin başarıyla sonuçlanması ve geçirilecek operasyonla ilgili kaygıların ortadan kalkmasıydı. Yapılan çalışmalar tek başına hastane yatışının bile \%10 düzeyinde anksiyeteye yol açtığını göstermiştir $(19,23)$. Preoperatif dönemde hastalarımızın \%66'sında yüksek kaygı, \%25'inde hafif kaygı, postoperatif dönemde ise \%26'sında yüksek kaygı, \%47'sinde hafif kaygı saptandı. Postoperatif dönemde, hasta kaygılarının hafif düzeyde de olsadevam etme nedeninin mevcut hospitalizasyon ve ağrı sebebiyle olduğu kanısındayız.

Çalışmada, spinal anestezi uygulanan grupta 6. ve 24. saatlerdeki VAS skorları genel anestezi uygulanan gruba göre daha yüksekti. Spinal anestezi grubunda 24.saat VAS skorları, 6.saat VAS skorlarından yüksek iken genel anestezi grubunda 24.saat VAS skorları, 6.saat VAS skorlarından düşüktü. Genel anestezi grubunda ağrının zaman içinde azalmasının, erken dönemde başlayan ve takip edilen uygun analjezi yönetimine bağlı olduğu kanısındayız. Postoperatif ağrının, spinal anestezi grubunda daha yüksek seyretmesini ise, ağrı yönetimine geç başlanması ve yetersiz kalınması ile ilişkili görmekteyiz. Postoperatif ağrı tedavisi için multimodal analjezik yaklaşımın preemptif kullanımı çok önemlidir ve altın standarttır (24).Multimodal analjezik yaklaşımda, sinerjik etki için farklı etki mekanizmalı ilaçlar ve uygulamalar birlikte kullanılır (25). Sezaryen operasyonlarında analjezikler, uygulanacak farmakoterapiden yenidoğanın etkilenmemesi için cerrahi öncesi yapılamamaktadır. Fakat ağrı tedavisinin, Genel Anestezi grubunda olduğu gibi bebek çıkımından sonra yapılması uygundur. Bu anket çalışmasında, spinal anestezi grubunda yüksek bulduğumuz 6 . ve 24. saatteki VAS skorları bize bu gruptaki analjezi uygulamasındaki eksikliğimizi göstermiştir.

Anlık anksiyetenin ağrı üzerinde etkili olduğu ve artan anksiyetenin; ağrılı durumun abartılmasına, ağrı toleransının azalmasına ve ağrı şiddetinin artmasına yol açtığı bildirilmiştir $(1,26)$. Taşdemir ve ark. preoperatif anksiyete ile artmış postoperatif ağrı arasında korelasyon olduğunu tespit etmiştir (14). Çalışmada hem spinal anestezi grubunda hem de genel anestezi grubunda VAS skorları ile preoperatif ve postoperatif anksiyete düzeyleri arasında korelasyon saptanmadı. Hastaların preoperatif mevcut anksiyetesinin ağrıdan ziyade; cerrahi bilinmezlik, yenidoğanın sağlığı ve getireceği sorumluluklardan, postoperatif anksiyetesinin de mevcut hospitalizasyondan kaynaklandığını ve bu nedenle anksiyete ile VAS skorları arasında korelasyon tespit etmediğimizi düşünüyoruz. Genel anestezi ile spinal anestezi memnuniyet düzeylerinin karşılaştırıldığı bir çalışmada; spinal anestezi ve genel anestezi uygulanan grupların memnuniyet düzeylerinin benzer olduğu tespit edilmiştir (27). Bir başka çalışmada spinal anestezi uygulanan grubun memnuniyetinin genel anestezi alan gruba göre daha yüksek olduğu saptanmış ve bu durum anne ile bebeğin temasının erken dönemde sağlanmasının, spinal anestezi ile sezaryen uygulanan hastalarda memnuniyeti arttırdığı şeklinde yorumlanmıştır (28). Acil olarak sezaryene alınan olgularda da spinal anestezi uygulanan hastaların memnuniyet düzeylerinin daha yüksek olduğu tespit edilmiştir (29). Çalışmamızda gruplar arası memnuniyet düzeyleri benzerdi. Anestezi yöntemi olarak hastanın kendi tercihinin uygulanmasının bu sonuçta etkili olduğunu düşünüyoruz. Çalışmada memnuniyet düzeylerini 
belirleyen parametrelerden ağrı alt grubunda; baş ağrısı şikayetispinal anestezi grubunda, boğaz ağrısı şikayeti genel anestezi grubunda fazlaydı. Spinal anestezi sonrası BOS kaybına bağlı baş ağrısı görülme sıklığı \% 4 ile \% 40 arasında değişir (30). Gebelerde üst solunum yolları; havayolu mukozasında hiperemi, hipersekresyon, mukozal ödem ve frajilite sebebiyle travmaya daha duyarlı hale gelir bu da boğaz ağrısı şikayetlerinin ortaya çıkışını kolaylaştırır (31).

Ağrının hoş olmayan bir duygu olduğu ve memnuniyeti düşürdüğü birçok çalışmada gösterilmiştir $(7,32)$. Açıkel ve ark. çalışmasında acil sezaryen operasyonuna alınan olgularda hastaların toplam QoR-40 skorları ile VAS skorları arasında korelasyon tespit edilmiştir. Bir başka çalışmada ise anksiyete düzeyi ile memnuniyet arasında negatif yönlü korelasyon olduğu tespit edilmiştir (32). Çalışmada her iki grupta da VAS skorları ile memnuniyet düzeyi arasında korelasyon saptanmadı. Ancak VAS skorları ile ağrı alt grubu arasında negatif korelasyon tespit edildi. Ağrının hoş olmayan bir duygu olması, ağrı arttıkça memnuniyetin azalması negatif korelasyonun sebebidir. Bununla birlikte memnuniyeti belirleyen tek komponent ağrı değildir. Rahatlık ve duygu durumunu içeren komponentler VAS skorları ile memnuniyet arasındaki korelasyonu etkilemiş olabilir. Ayrıca hastanın ağrının oluşacağını önceden bilmesi ve bu duruma psikolojik olarak kendini hazırlaması nedeniyle hissedilen ağrı genel memnuniyeti etkilememiş olabilir.

Literatürde preoperatif ve postoperatif anksiyete düzeylerinin hasta memnuniyetini azalttığı veya etkilemediği yönünde farklı bilgiler vardır $(22,33,34)$. Çalışmada her iki grupta da preoperatif ve postoperatif anksiyete düzeyleri ile memnuniyet arasında korelasyon saptanmadı. Memnuniyet anketinde yapılan değerlendirmelerin; emosyonel durumun yanısıra fiziksel konfor, psikolojik destek, fiziksel bağımlılık ve ağrı ile de ilgili olmasının korelasyon saptanmamasında etkili olduğunu düşünüyoruz. Çalışmaya, dışlama ve dahil edilme kriterleri arasında hastalarda anksiyeteye yol açabilecek gestasyonel ve medikal durumların yer almaması araştırmamızın limitasyonunu oluşturmuştur.

Sonuç olarak; elektif sezaryen operasyonlarında tercih edilen anestezi yönteminin anksiyete ve memnuniyet üzerine etkisinin olmadığı ve postoperatif dönemde etkin analjezisağlanması için ağrı algoritmamızın gözden geçirilmesinin hasta memnuniyet düzeyini dolayısıyla hizmet kalitesini artıracağı kanısına varıldı.
Çıkar Çatışması: Çalışmada herhangi bir çıkar çatışması yoktur.

Finansal Çıkar Çatışması: Çalışmada herhangi bir finansal çıkar çatışması yoktur.

Yazışma Adresi: Sinan Kızılkaya, Sinan Kızılkaya, Akdeniz Üniversitesi Anesteziyoloji ve Reanimasyon Anabilim Dalı, Yoğun Bakım Bilim Dalı, Antalya,Türkiye

Telefon: 05543311086

e-mail:drsinankizilkaya@hotmail.com

\section{KAYNAKLAR}

1. Güz H, Doğanay Z. Lomber disk hernisi nedeniyle ameliyat olan hastalarda ameliyat öncesi anksiyete. Nöropsikiyatri Arşivi 2003;40:36-9.

2. Akildiz M, Aksoy $Y$, Kaydu A, et al. Elektif sezaryen ameliyatlarında anestezi yönteminin preoperatif anksiyete düzeylerine etkisi. Turk J Anaesthesiol Reanim 2017;45(1):3640.

3. Labarere J, Francois $\mathrm{P}$, Auquier $\mathrm{P}$, et al. Development of a French in patient satisfaction questionnaire. Int J Qual Health C 2001;13:99-108.

4. Mpinganjira M. Understanding service quality and patients at is faction in private medical practice: A case study. Afr J Bus Manage 2011;5:3690-8.

5. Carlucci D, Renna P and Schiuma G. Evaluating service quality dimensions as antecedents to out patients at is faction using back propagation neural network. Healthcare Manag Sci 2013;16:37-44.

6. Aydemir Ö, Köroğlu E. Psikiyatride kullanılan klinik ölçekler. Ankara, Hacettepe Taş Kitabevi 2000; 153-63.

7. Myles P, Williams D, Hendrata M, et al. Patients at is faction after anaesthesia and surgery: Results of a prospective survey of 10,811 patients. Br J Anaesth 2000;84(1):6-10.

8. Çevik Ü, Keleş S, Keser M. Astımlı çocuğu olan anne ve babalara verilen hemşirelik eğitiminin anksiyete düzeylerine etkisi. Genel Tıp Dergisi 2006;16(5):53-9.

9. Çuhadar D, Karadağ G. Koroner anjiografi uygulanacak hasta ve yakınlarının kaygı düzeylerinin belirlenmesi. Sağlık ve Toplum 2006;16:56-62.

10. Erdem D, Ugiş C, Albayrak MD, et al. Perianal bölge ameliyatı yapılacak hastalarda uygulanan anestezi yöntemlerinin preoperatif ve postoperatif anksiyete ve ağrı düzeylerine etkisi. Bakırköy Tıp Dergisi 2011;7:11-6.

11. Beilin $\mathrm{Y}$, Rosenblatt MA, Bodian CA, et al. Information and concerns about obstetric anesthesia: A survey of 320 obstetric patients. Int J Obstet Anesth 1996;5:145-51.

12. Jafar MF, Khan FA. Frequency of preoperative anxiety in Pakistan isurgical patients. J Pak Med Assoc 2009;59:35963.

13. Aykent R, Serhat K, Emre Ü, et al. Preoperatif anksiyete nedenleri ve değerlendirilmesi: APAIS ve STAI skorlarının karşılaştırılması. Turkiye Klinikleri J Anest Reanim 2007;5 (1):7-13.

14. Taşdemir A, Erakgün A, Deniz MN, et al. Preoperatif bilgilendirme yapılan hastalarda ameliyat öncesi ve sonrası anksiyete düzeylerinin state-trait anxiety inventory test ile karşılaştırılması. Turk J Anaesth Reanim 2013;41:44-9.

15. Küpeli İ, Kuyrukluyıldız U, Taş S, et al. Rejyonal anestezi/ periferik sinir bloğu ile genel anestezinin preoperatif anksiyeteye etkilerinin karşılaştırılması. Turkiye Klinikleri J Anest Reanim 2016;14 (1):1-6. 
16. Maheshwari D, Ismail S. Preoperative anxiety in patients select in geither general orregional anesthesia for elective cesarean section. J Anaesthesiol Clin Pharmacol 2015;31(2):196-200.

17. Deliktaş HK, Açıkgöz T, Çelik S. Elektif operasyon planlanan hastaların premedikasyon odasında bekleme sürelerinin anksiyete seviyelerine etkisi. Şişli Etfal Hastanesi Tıp Bülteni 2017;51(4):283-92.

18. Çopurlar CK, Kartal M. Sağlık okuryazarlığı nedir? Nasıl değerlendirilir? Neden önemli? TJFM\&PC 2016;10(1):42-7.

19. Yılmaz ER, Bulut SD, Eryılmaz F, et al. Beyin cerrahi servisinde lomber disk hernisi tanısı ile yatan hastalarda anksiyete - depresyon düzeyleri ve hasta iyileşmesi üzerinde etkileri. Ortadoğu Tıp Dergisi 2014;6 (3):111-21.

20. Erfidan S. Anestezi polikliniğine başvuran hastalarda anksiyete düzeyinin ve nedenlerinin değerlendirilmesi (Uzmanlık tezi) İzmir, 2015.

21. Erci B, Sezgin S, Kaçmaz Z. The impact of the rapeutic relation ship on preoperative and postoperative patient anxiety. Australıan Journal of Advanced Nursıng 2004;26:5966.

22. Hobson JA, Slade P, Wrench IJ, et al. Preoperative anxiety and postoperative satisfaction in women under going elective caesarean section. Int J Obstet Anesth 2006;15:18-23.

23. Aslan S, Candansayar S, Coşar B, et al. Bir üniversite hastanesinde bir yıl süresince gerçekleştirilen psikiyatri konsültasyon hizmetlerinin değerlendirilmesi. Yeni Symposium Dergisi 2003;41:31-8.

24. Özyalçın S. Preemptif analjezi. Ağrı dergisi 1995;7:5-10.

25. Karim S. Ladha, Elisabetta Patorno, et al. Impact of perioperative epidural placement on postdischarge opioid use in patients undergoing abdominal surgery. Anesthesiology 2016;124(2):396-403.
26. Doering BG. Postoperatif ağrı ve psikolojik faktörler. Doktor Dergisi 2009;51:94-6.

27. Uysal Aİ, Güner Ö, İnal FY, et al. Tokat devlet hastanesinde genel ve rejyonal anestezi uygulanan hastaların anestezi bilgi düzeyini ve memnuniyetini değerlendirme anketi. Çağdaş Tıp Dergisi 2013;3(2):82-7.

28. Hemanth Kumar V, Jahagirdar SM, Athiraman UK, et al. Study of patient satisfaction and self-expressed problems after emergency caesare an delivery under subarach noidblock. Indian J Anaesth 2014;58:149-53.

29. Açıkel A, Öztürk T, Göker A, et al. Acil sezaryen operasyonlarında genel ve spinal anestezinin hasta memnuniyeti yönünden karşılaştırılması. Turk J Anaesthesiol Reanim 2017;45:41-6.

30. Mordecai MM, Brull SJ. Spinal anesthesia. Curr Opin Anaesthesiol 2005;18(5):527-33.

31. Handan Özcan, Ümran Oskay. Gebelikte fazla görülen solunum sistem hastalıkları ve bakımı. Ege Üniversitesi Hemşirelik Fakültesi Dergisi 2014;30(3):80-91.

32. Turhan Y. Elektif cerrahi operasyon planlanan hastalarda preoperatif ve postoperatif anksiyetenin hasta memnuniyeti ile ilişkisi. (Uzmanlık tezi) Adana, 2007.

33. Yılmaz E, Aydın E. Cerrahi girişim yapılan hastalarda ameliyat öncesi-sonrası anksiyetenin derlenme kalitesine etkisi. Fırat Sağlık Hizmetleri Dergisi 2013;8(23):80-95.

34. Aslan B, Arıkan M, Gedikli A, et al. Gebe hastalarda preoperatif anksiyete sebepleri ve değerlendirilmesi: STAI skorlarının karşılaştırılması. Ortadoğu Tıp Dergisi 2014;6 (3):129-35. 